\title{
Dental Implant Failure Rate and Marginal Bone Loss in Transplanted Patients: A Systematic Review and Meta-Analysis
}

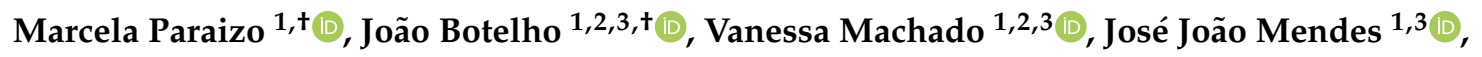 \\ Ricardo Alves ${ }^{1,2}$, Paulo Mascarenhas ${ }^{1,3, *}$ and José Maria Cardoso ${ }^{2} \mathbb{D}$ \\ 1 Clinical Research Unit (CRU), Centro de Investigação Interdisciplinar Egas Moniz (CiiEM), \\ Instituto Universitário Egas Moniz, 2829-511 Caparica, Portugal; marcelaparaizo@hotmail.com (M.P.); \\ jbotelho@egasmoniz.edu.pt (J.B.); vmachado@egasmoniz.edu.pt (V.M.); jmendes@egasmoniz.edu.pt (J.J.M.); \\ ralves@egasmoniz.edu.pt (R.A.) \\ 2 Periodontology Department, Clinical Research Unit (CRU), CiiEM, Egas Moniz-Cooperativa de Ensino \\ Superior, CRL, 2829-511 Almada, Portugal; josencardoso@hotmail.com \\ 3 Evidence-Based Hub, CiiEM, Egas Moniz-Cooperativa de Ensino Superior, CRL, \\ 2829-511 Almada, Portugal \\ * Correspondence: pmascarenhas@egasmoniz.edu.pt; Tel.: +351-212946800 \\ + Marcela Paraizo and João Botelho are equally first authors.
}

Received: 17 September 2020; Accepted: 5 October 2020; Published: 10 October 2020

\begin{abstract}
This systematic review investigates the failure rate and marginal bone loss (MBL) of dental implants placed in patients undergoing solid-organ transplant (SOT) compared to healthy controls. Three databases (PubMed, Web of Sciences, and the Cochrane Library) were searched up to June 2020 (PROSPERO CRD42019124896). Case-control and cohort studies reporting data failure rate and marginal bone loss (MBL) of dental implants placed in SOT patients were included. The risk of bias of observational studies was assessed through the Newcastle-Ottawa Scale (NOS). Four case-control studies fulfilled the inclusion criteria; all had low risk of bias. Meta-analyses revealed consistently lower implant failure rate than control populations at patient and implant levels. SOT patients had a significant difference of $-18 \%$ ( $p$-value < 0.001) MBL compared to healthy patients. SOT status poses no serious threat to implant survival. Overall, this group of patients presented lower levels of dental implant failure rate and marginal bone loss compared to otherwise healthy patients. Further intervention trials with larger sample size and longer follow-ups are necessary to confirm these summarized results.
\end{abstract}

Keywords: transplantation; dental implant; marginal bone loss; implant failure rate; systematic review; periodontitis; periodontal diseases; oral health

\section{Introduction}

Dental implants restore missing teeth, in both partially and fully edentulous patients [1-3]. Further, implants have consistent long-term success, with high survival rates and significant improvements in the patient's function, aesthetics, and quality of life $[4,5]$.

It is, however, unclear what the impact of systemic diseases is on the outcome of implant therapy and whether medically compromised patients may have different success and survival rates [6,7]. Systemic diseases and medications may directly affect oral tissues, either by increasing the susceptibility to infections or by interfering with wound healing or bone metabolism, which may directly influence implant osseointegration and result in early or late implant failures $[8,9]$.

The replacement of a damaged organ by a healthy organ has been one of the most extraordinary medical achievements ever achieved $[10,11]$. According to the Global Observatory on Donation 
and Transplant (GODT), the number of solid organ transplants (SOT) increased 7.5\% in 2016 [12]. According to GODT, in 2017, more than 139 thousand organ transplants were performed, corresponding to 16 organ transplants per hour. To prevent organ rejection, these patients undergo a chronic regimen of immunosuppressants, which puts them at higher risk of infections and inflammation [13-16]. In patients taking these medications, there is evidence that wound healing and bone metabolism may be impaired, due to either inhibition of osteoblast function and osteogenesis or to a concomitant increase of bone resorption and osteoporosis, which may result in decreased bone-to-implant contact [17-20]. In addition, these patients also often take concomitant systemic steroid medication, which can also cause wound healing alteration and opportunistic colonisation by oral pathogens $[10,21]$.

Overall medical improvements have contributed to high standards of quality of life in SOT patients, and hence, it is very common that these patients seek dental implant therapy once recovered from the surgical procedure $[10,11]$. Nevertheless, we bear in mind that dental implant therapy may pose a risk to the development of peri-implantitis, an inflammatory infection around the implant caused by dental plaque accumulation. [22] This accumulation may serve as reservoir for several types of microbials that can possibly trigger infectious reactions in SOT patients [23,24]. Additionally, SOT patients are at more risk to life-threatening infections or malignancies, and these may precipitate with increased morbidity and mortality, adverse effects on the graft functioning, or survival [25].

Evidence on the outcome of implant therapy in SOT patients is scarce [4], mostly reported in cases of liver transplant patients $[8,26]$. There are some prospective controlled studies evaluating dental implants in these patients [27], liver transplant patients [28], in a combined sample of heart and liver transplant patients, and in renal transplant patients [29]. These publications have reported successful outcomes of implant therapy in SOT individuals; however, the existing evidence on the long-term outcome of implant therapy in large samples of these populations is scarce.

Therefore, the aim of this review was to evaluate the failure rate and marginal bone loss (MBL) of dental implants placed in SOT patients compared to healthy controls.

\section{Materials and Methods}

\subsection{Protocol and Registration}

This review was submitted to the National Institute for Health Research PROSPERO, International Prospective Register of Systematic Review database (ID number: CRD42019124896). We planned this review under the PRISMA statement (Table S1 in Supplementary Materials) [30].

\subsection{Focus Question and Eligibility Criteria}

We set the following research question: "In adults, do dental implants placed in solid-organ transplanted individuals have comparable survival rates to systemically healthy individuals?" with the following PICO:

- $\quad \mathrm{P}$ (Population): Solid-organ transplanted adult humans ( $\geq 18$ years old).

- I (Intervention): Dental implant placement.

- C (Comparator): Adult healthy controls.

- O (Outcome): Implant failure rate and marginal bone loss.

To address this PICO question, the following inclusion criteria were applied:

- Randomized clinical trials (RCTs) and non-RCTs (retrospective and prospective case-control and cohort studies)

- Studies reporting implant survival, or otherwise failure, in transplanted patients, with or without non-transplanted patients as reference

- Studies reporting marginal bone loss data

- $\quad$ Defined SOT patients 
- Studies reporting follow-up period of placed dental implants

- Studies with follow-ups of at least 6 months after placement of the dental implant.

As exclusion criteria, we defined: Studies with patients with necessary bone graft and/or guided bone regeneration procedures, and patients undergoing radiation treatment of the head and neck.

There were no restrictions concerning race, origin, year of publication, or language. Only published, peer-reviewed journal articles were considered eligible.

\subsection{Search Strategy}

We conducted a computerized literature search using the electronic databases of PubMed, Web of Sciences, and the Cochrane Library from the earliest data available until June 2020. We merged keywords and subject headings in accordance with the thesaurus of each database and applied exploded subject headings. The following syntax was made to conduct a search in PubMed: ("dental implants") AND ("survival rate" OR survival OR "marginal bone loss" OR "marginal loss" OR "bone loss") AND (transplantation OR "organ transplantation" OR "transplantation, organ" OR "tissue transplantation" OR "transplantation, tissue" OR "heart transplantation" OR "kidney transplantation" OR "liver transplantation" OR "lung transplantation" OR "pancreas transplantation"). Additional relevant literature was included after a manual search across the selected articles' reference lists.

There were no restrictions other than the search terms.

\subsection{Study Process}

Two independent investigators (M.P. and P.M.) examined the title and abstract of available studies for the first inclusion phase. We resolved disagreement through a third reviewer (J.B.). The final selection of the studies was carried out independently by the authors, who reviewed the full text of the selected papers according to the inclusion criteria mentioned above.

A predefined table was created to extract essential data from each eligible article, including the first author's name, study design, publication year, inclusion/exclusion criteria, number of participants, and rationale for failure. Clinical implant measures included implant failure rate and marginal bone loss. All data were extracted independently by two reviewers. The authors were contacted when necessary for additional data clarification.

\subsection{Risk of Bias (RoB) in Individual Studies}

Methodological quality was independently performed by two calibrated authors (V.M. and J.B.) using the Newcastle-Ottawa Scale (NOS) for cohort studies. Regarding this tool, we scored across three categories: Studies with 7-9 stars as of low RoB, studies with 5-6 stars as of moderate RoB, whilst studies with fewer than 5 stars were deemed of high RoB. Any doubt was resolved by discussion with a third author.

\subsection{Statistical Analysis}

All statistical analyses were performed in R version 3.4.1 (R Studio Team 2018). Incidence rate ratios (IRR) and mean ratios (MR) calculations, including confidence intervals and plots, were calculated through the metafor $\mathrm{R}$ package with control data as a reference (denominator). Meta-analysis procedures followed Random-effects Restricted Maximum Likelihood models with log transformed data. Overall results were displayed in exponentially back transformed data forest plots. Due to the reduced number of studies selected for the quantitative synthesis, sensitivity and publication bias analysis were skipped. Heterogeneity was evaluated by means of the I 2 index. Assumption of statistical significance was set at $p<0.05$. 


\section{Results}

\subsection{Characteristics of Included Studies}

The search strategy identified a total of 970 possibly relevant articles. After duplicates removal, 947 papers were judged against the eligibility criteria and 867 were excluded. Out of eight papers, four were further excluded with reasons (Table S2), and a total of four case-control studies were included for quantitative and qualitative synthesis (Figure 1; Table 1). Inter-examiner reliability was considered as excellent (kappa score $=0.9754,95 \% \mathrm{CI}: 0.9656-0.9852$ ).

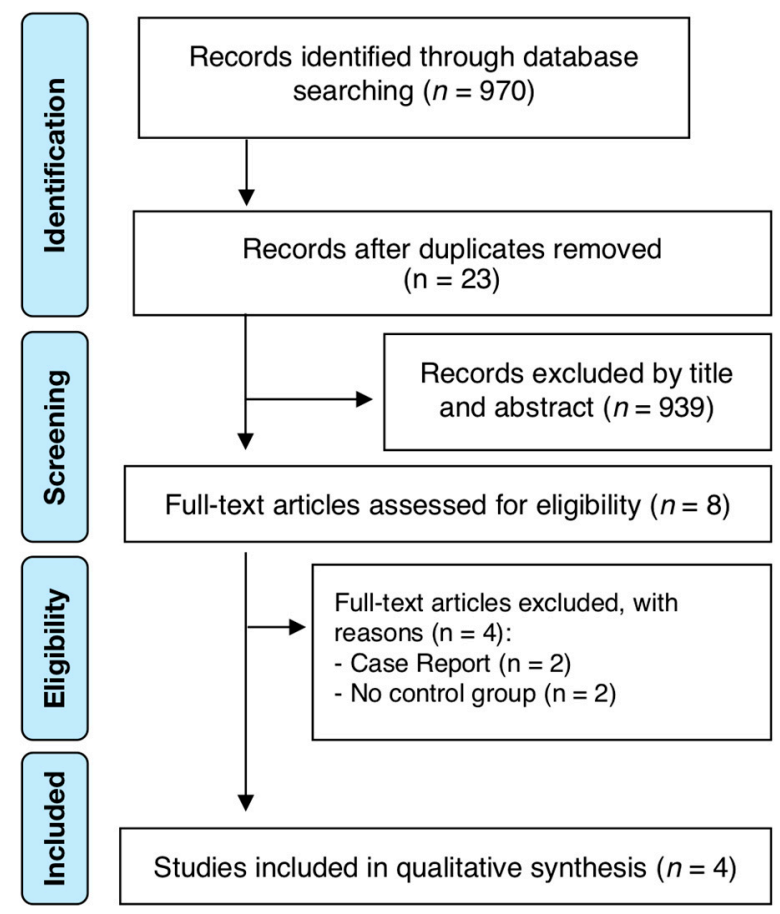

Figure 1. PRISMA flow chart.

Table 1. Newcastle-Ottawa Scale assessment.

\begin{tabular}{cccccccccc}
\hline Study (Year) (Country) & $\mathbf{1}$ & $\mathbf{2}$ & $\mathbf{3}$ & $\mathbf{4}$ & $\mathbf{5}$ & $\mathbf{6}$ & $\mathbf{7}$ & $\mathbf{8}$ & Score (Risk of Bias) \\
\hline Hernández et al. (2019) (Spain) [28] & a & a & a & a & a/b & b & a & a & 9 (Low) \\
Radzewski and Osmola (2019) (Poland) [31] & d & c & a & a & a/b & b & a & a & 7 (Low) \\
Paredes et al. (2018) (Spain) [27] & a & a & a & a & a/b & b & a & a & 9 (Low) \\
Montebugnoli et al. (2015) (Italy) [32] & c & c & a & a & a/b & b & a & a & 7 (Low) \\
\hline
\end{tabular}

\subsection{Risk of Bias (RoB) in Individual Studies}

All cohort studies presented low RoB, with two with 9/9 and four with 7/9 scores (Table 2). The main reason for bias arose from the representativeness of the cases $(33.3 \%, n=2)$ and controls $(50.0 \%, n=3)$. In the ascertainment of exposure, this involved demonstration that outcome of interest was not present at the start of the study, comparability of cohorts on the basis of the design or analysis, usability of the same method of ascertainment for cases and controls, and adequate follow-up. 
Table 2. Studies Characteristics.

\begin{tabular}{|c|c|c|c|c|c|c|c|c|c|c|}
\hline Study & Effect Size & SOT Sample & Control & $\begin{array}{l}\text { Exclusion } \\
\text { Criteria }\end{array}$ & $\begin{array}{c}\text { Clinical } \\
\text { Environment }\end{array}$ & Immunotherapy & $\begin{array}{c}\text { Implant } \\
\text { Characteristics }\end{array}$ & $\begin{array}{c}\text { Implant } \\
\text { Follow-Up }\end{array}$ & Outcome & $\begin{array}{l}\text { Funding } \\
\text { Sources }\end{array}$ \\
\hline $\begin{array}{l}\text { Hernández et al. } \\
\text { (2019) (Spain) [28] }\end{array}$ & $\begin{array}{l}\text { Implant failure } \\
\text { incidence rate } \\
\text { and MBL }\end{array}$ & $\begin{array}{l}25 \text { partially } \\
\text { edentulous } \\
\text { Renal SOT who } \\
\text { received } 79 \\
\text { dental implants }\end{array}$ & $\begin{array}{l}28 \text { matched } \\
\text { controls who } \\
\text { received } 86 \\
\text { dental implants }\end{array}$ & $\begin{array}{l}\text { Suffering from } \\
\text { untreated } \\
\text { periodontitis, } \\
\text { being smokers, } \\
\text { or having a } \\
\text { medical history } \\
\text { of radiotherapy, } \\
\text { severe or } \\
\text { uncontrolled } \\
\text { metabolic } \\
\text { diseases, or lack } \\
\text { of compliance. }\end{array}$ & Private practice & $\begin{array}{c}\text { Prednisone, } \\
\text { Tacrolimus + } \\
\text { Mycophenolate } \\
\text { Mofetil (15 } \\
\text { patients) } \\
\\
\text { Prednisone, } \\
\text { Cyclosporine A + } \\
\text { Mycophenolate } \\
\text { Mofetil ( } 9 \\
\text { patients) } \\
\text { Prednisone, } \\
\text { Cyclosporine A + } \\
\text { Azathioprine (2 } \\
\text { patients) } \\
\text { Prednisone + } \\
\text { Tacrolimus or } \\
\text { Prednisone plus } \\
\text { Cyclosporine A (2 } \\
\text { patients) }\end{array}$ & $\begin{array}{c}\text { Ti Unite, Nobel } \\
\text { Biocare } 3.75 / 4.00 \\
\text { or } 5.00 \mathrm{~mm} \\
\text { diameter and } \\
8 / 8.5 / 10 / 11.5 / 13 \\
\text { or } 15 \mathrm{~mm} \text { length }\end{array}$ & $\begin{array}{l}\text { Mean follow-up } \\
\text { of } 9.7 \text { years }\end{array}$ & $\begin{array}{l}\text { Implant survival } \\
\text { rate was over } \\
98 \% \text { in both test } \\
\text { and control } \\
\text { groups. Slightly } \\
\text { increased } \\
\text { marginal bone } \\
\text { loss in the } \\
\text { control group. }\end{array}$ & $\begin{array}{l}\text { Dentaid S. L. } \\
\text { provided partial } \\
\text { support }\end{array}$ \\
\hline $\begin{array}{c}\text { Radzewski and } \\
\text { Osmola (2019) } \\
\text { (Poland) [31] }\end{array}$ & $\begin{array}{l}\text { Implant failure } \\
\text { incidence rate } \\
\text { and MBL }\end{array}$ & $\begin{array}{l}21 \text { organ } \\
\text { transplant } \\
\text { immunosuppressed } \\
\text { patients (Kidney, } \\
\text { Pancreas, and } \\
\text { Liver) who } \\
\text { received } 24 \\
\text { dental implants }\end{array}$ & $\begin{array}{l}15 \text { matched } \\
\text { controls who } \\
\text { received } 15 \\
\text { dental implants }\end{array}$ & $\begin{array}{l}\text { Patients with } \\
\text { active } \\
\text { periodontal } \\
\text { disease, } \\
\text { substantial } \\
\text { occlusion } \\
\text { disorders, bone } \\
\text { diseases, blood } \\
\text { coagulation } \\
\text { disorders, } \\
\text { untreated } \\
\text { dyslipidemia, or } \\
\text { were a smoker. }\end{array}$ & $\begin{array}{l}\text { University } \\
\text { based }\end{array}$ & $\begin{array}{c}\text { Tacrolimus } \\
\text { (majority) or } \\
\text { Cyclosporine, } \\
\text { Sirolimus, or } \\
\text { Mycophenolate } \\
\text { Mofetill, Sirolimus } \\
\text { (12 patients) }\end{array}$ & $\begin{array}{l}\text { Naturactis; ETK, } \\
\text { Sallanches, } \\
\text { France }\end{array}$ & 2 years & $\begin{array}{l}\text { Implant stability } \\
\text { and bone loss } \\
\text { were not any } \\
\text { different from } \\
\text { those in healthy } \\
\text { people. }\end{array}$ & N/A \\
\hline
\end{tabular}


Table 2. Cont.

\begin{tabular}{|c|c|c|c|c|c|c|c|c|c|c|}
\hline Study & Effect Size & SOT Sample & Control & $\begin{array}{c}\text { Exclusion } \\
\text { Criteria }\end{array}$ & $\begin{array}{c}\text { Clinical } \\
\text { Environment }\end{array}$ & Immunotherapy & $\begin{array}{c}\text { Implant } \\
\text { Characteristics }\end{array}$ & $\begin{array}{c}\text { Implant } \\
\text { Follow-Up }\end{array}$ & Outcome & $\begin{array}{l}\text { Funding } \\
\text { Sources }\end{array}$ \\
\hline $\begin{array}{l}\text { Paredes et al. (2018) } \\
\quad \text { (Spain) [27] }\end{array}$ & $\begin{array}{l}\text { Implant failure } \\
\text { incidence rate } \\
\text { and MBL }\end{array}$ & $\begin{array}{l}14 \\
\text { pharmacologically } \\
\text { immunosuppressed } \\
\text { Liver TP with } 48 \\
\text { dental implants }\end{array}$ & $\begin{array}{c}16 \text { matched } \\
\text { controls who } \\
\text { received } 53 \\
\text { dental implants }\end{array}$ & $\begin{array}{l}\text { Suffering from } \\
\text { active } \\
\text { periodontitis, } \\
\text { being smokers, } \\
\text { or having a } \\
\text { medical history } \\
\text { of radiotherapy, } \\
\text { severe or } \\
\text { uncontrolled } \\
\text { metabolic } \\
\text { diseases, or lack } \\
\text { of compliance. }\end{array}$ & Private practice & $\begin{array}{c}\text { Prednisone + } \\
\text { Cyclosporin A + } \\
\text { Azathioprine (2 } \\
\text { patients) } \\
\\
\text { Prednisone + } \\
\text { Cyclosporin A + } \\
\text { Mycophenolate } \\
\text { Mofetil (5 } \\
\text { patients) } \\
\text { Prednisone + } \\
\text { Tacrolimus + } \\
\text { Mycophenolate } \\
\text { Mofetil (8 } \\
\text { patients) } \\
\text { Prednisone + } \\
\text { Cyclosporin A (1 } \\
\text { patient) }\end{array}$ & $\begin{array}{c}\text { Ti Unite }{ }^{\circledR} ; \\
\text { Nobel Biocare } \\
\text { S.A., } \\
\text { Gothenburg, } \\
\text { Sweden } 3.75,4 \\
\& 5 \mathrm{~mm} \\
\text { diameter }\end{array}$ & $\begin{array}{l}\text { Mean follow-up } \\
\text { of }+8 \text { years }\end{array}$ & $\begin{array}{l}100 \% \text { implant } \\
\text { survival in liver } \\
\text { transplant } \\
\text { patients after the } \\
\text { pharmacological } \\
\text { immunosuppression }\end{array}$ & $\begin{array}{l}\text { Dentaid S. L. } \\
\text { provided partial } \\
\text { support } \\
\text { n }\end{array}$ \\
\hline $\begin{array}{l}\text { Montebugnoli et al. } \\
\text { (2015) (Italy) [32] }\end{array}$ & MBL & $\begin{array}{c}13 \\
\text { organ-transplanted } \\
\text { (11 hearts, two } \\
\text { livers) patients } \\
\text { who received } 29 \\
\text { submerged } \\
\text { dental implants }\end{array}$ & $\begin{array}{l}15 \text { matched } \\
\text { controls who } \\
\text { received } 15 \\
\text { dental implants }\end{array}$ & $\begin{array}{l}\text { Previous } \\
\text { irradiation of } \\
\text { the head and } \\
\text { neck region, } \\
\text { alcohol or drug } \\
\text { abuse, or } \\
\text { psychiatric } \\
\text { disorders that } \\
\text { made it difficult } \\
\text { to obtain } \\
\text { informed } \\
\text { consent, severe } \\
\text { bruxism or } \\
\text { clenching habits, } \\
\text { smoking, and } \\
\text { cyclosporine-induced } \\
\text { gingival } \\
\text { overgrowth. }\end{array}$ & $\begin{array}{l}\text { University } \\
\text { based }\end{array}$ & $\begin{array}{c}\text { Cyclosporin (11 } \\
\text { patients) and } \\
\text { Tacrolimus (2 } \\
\text { patients) }\end{array}$ & $\begin{array}{c}\text { Standard } \\
\text { tapered } \\
\text { implants with } \\
\text { anodized } \\
\text { surfaces } \\
\text { (NobelReplace } \\
\text { Tapered Groovy, } \\
\text { Nobel Biocare } \\
\text { AB, Gothenburg, } \\
\text { Sweden). }+3.5 \\
\text { mm diameter } \\
\text { and }+8 \mathrm{~mm} \\
\text { length }\end{array}$ & 1 year & $\begin{array}{l}\text { Implant failure } \\
\text { and bone loss } \\
\text { were equivalent } \\
\text { to those in } \\
\text { control }\end{array}$ & No funding \\
\hline
\end{tabular}

MBL-Mean Bone Loss; NA—Not applicable. 


\subsection{Synthesis of Results}

\subsubsection{Implant Failure Rate}

To investigate the likelihood of failure rate, four studies were selected to synthesize estimates for implants (Figure 2) and patients' prospects (Figure 3). Implant failure was perceived as a very rare event in both SOT and healthy populations. For the implant view, SOT patients presented, on average, consistently lower implant failure rate than control populations (Incidence Rate Ratio 0.52, 95\% Confidence Interval (CI): 0.09-2.99). The level of heterogeneity was considered to be residual (I2 $=0 \%$; Figure 2).

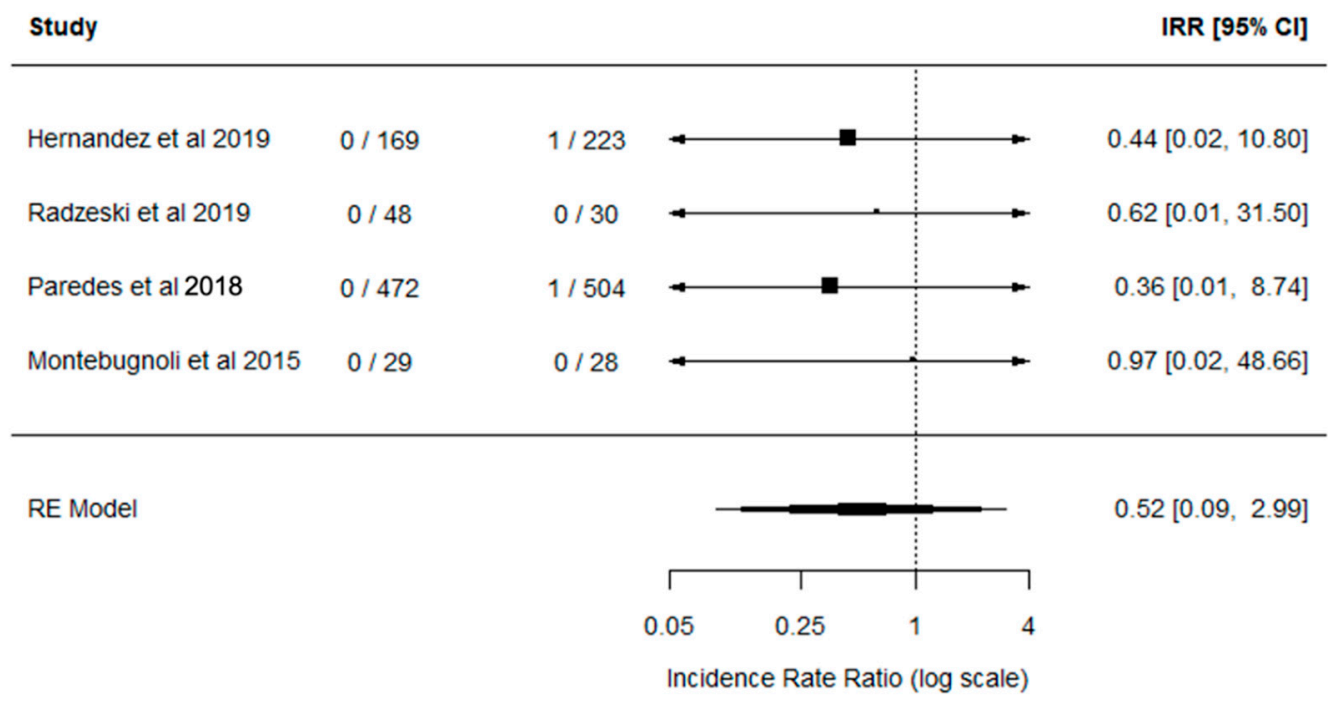

Figure 2. Forest plot of studies with Implants Incidence Rate Ratio values comparing transplanted and healthy patients. Mean effect size estimates have been calculated with $95 \%$ confidence intervals and are shown in the figure. Area of the squares represent sample size. Continuous horizontal lines and diamonds width represents 95\% confidence interval. IRR-Incidence Rate Ratio; RE-Random Effects.

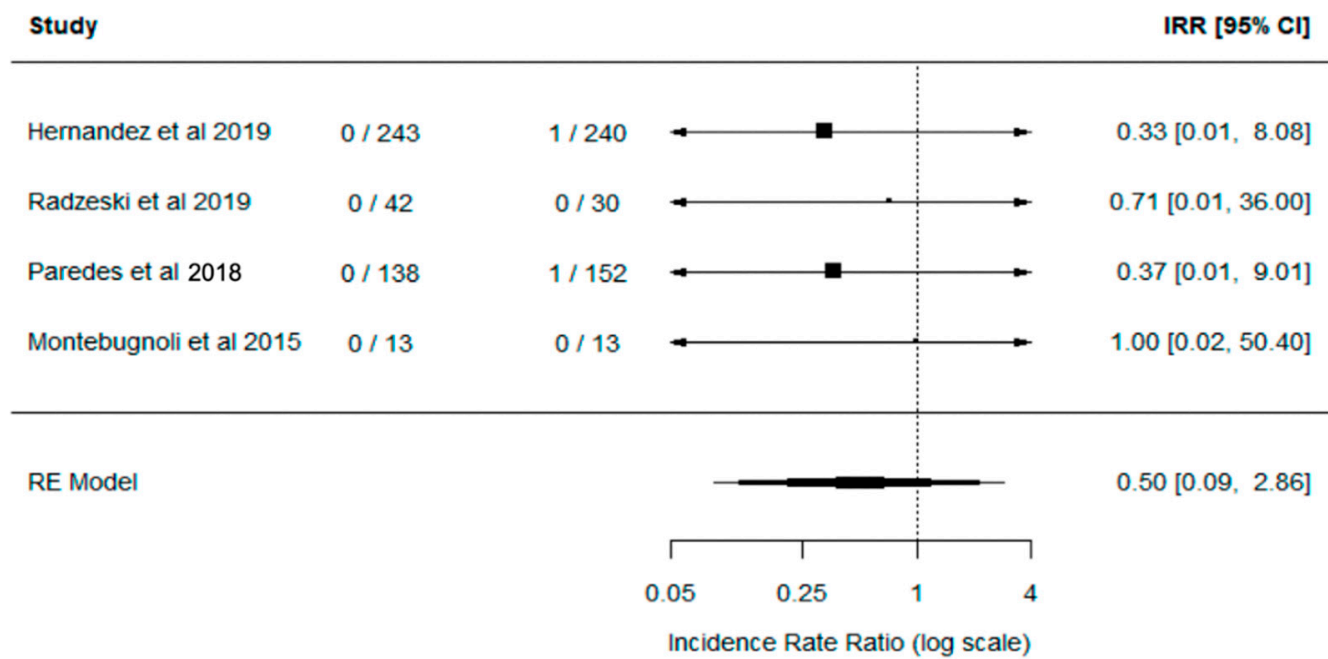

Figure 3. Forest plot of studies with Patients Incidence Rate Ratio values comparing transplanted and healthy patients. Mean effect size estimates have been calculated with $95 \%$ confidence intervals and are shown in the figure. Area of the squares represent sample size. Continuous horizontal lines and diamonds width represents $95 \%$ confidence interval. 
In terms of patient analysis, SOT populations presented half of the overall implant failure rate of healthy controls (Incidence Rate Ratio 0.50, 95\% Confidence Interval (CI): 0.09-2.86), with high consistency (I2 $=0 \%$; Figure 3).

\subsubsection{Marginal Bone Loss}

Regarding the assessment of MBL of implants, SOT patients had a significant difference of $-18 \%$ ( $p$-value $<0.001$ ) of MBL towards healthy patients (Ratio of Means $0.82,95 \%$ CI: $0.71-0.95$ ). Overall, this outcome resulted from a very homogeneous synthesis (I2 $=0 \%$; Figure 4 ).

\begin{tabular}{lll}
\hline Hernandez et al 2019 \\
Radzeski et al 2019 \\
Paredes et al 2018 \\
Montebugnoli et al 2015 \\
\hline RE Model
\end{tabular}

Figure 4. Forest plot of studies with Marginal Bone Loss Rate of Means comparing transplanted and healthy patients. Mean effect size estimates have been calculated with $95 \%$ confidence intervals and are shown in the figure. Area of the squares represent sample size. Continuous horizontal lines and diamonds width represents $95 \%$ confidence interval.

\section{Discussion}

\subsection{Summary of Main Findings}

This systematic review provides a comprehensive assessment of implant failure rate and marginal bone loss (MBL) of dental implants placed in SOT patients compared with otherwise healthy individuals. The quantitative analysis provided by case-control studies revealed that SOT patients had lower incidence of implant failures and marginal bone loss than control patients. Nevertheless, these implant clinical shortcomings were collectively seen as rare events and are consistent with previous reviews [33,34].

Our results are novel as, to the best of our knowledge, this is the first systematic review to provide concrete evidence on the dental implant success characteristics in SOT patients. A previous systematic review on immune compromised patients reported a dental implant success of $100 \%$ in SOT patients [35]; however, this result accounted for case reports, which is highly discouraged [36]. In addition, the number of SOT cases is expected to increase globally in the years to come [12] and, therefore, implantology care in SOT cases will become more standard in daily practice.

When compared to healthy patients, the lower rates of dental implant failure and MBL in SOT patients are intriguing. Although far from being completely understood, we might hypothesize that the health preoccupation of SOT patients might contribute to maintaining healthier states, as any health complication can have serious consequences. On the other hand, we might have to consider a possible biological reason for these failure rate differences, for example, the chronic use of immunosuppressors. However, this urges clarification in future studies.

Nevertheless, the obtained implant failure results differences between SOT and control patients were not significant $(p>0.05)$, and chance may have had a role here, probably due to implant failure being a very rare event in the studied conditions and the limited sample size from the selected studies. Furthermore, in a previous meta-analysis in immunocompromised patients, no significant effect of Immunosuppressant therapy was found on implant survival [35]. 
Despite that there were no differences between SOT with control patients, we emphasize that SOT presents high prevalence of cytomegalovirus (CMV) and Epstein-Barr virus (EBV) co-infections, increasing morbidity and mortality [37]. Remarkably, herpesviruses like CMV or EBV were recently associated to be in higher frequency in peri-implantitis lesions [38], which may result in the clinical failure of the implant. Beyond the implant success, we should be aware that peri-implantitis pockets may be a reservoir for herpesviruses to enter into the bloodstream via an ulcerated epithelium. Therefore, these local infections may constitute a risk for the SOT patient. However, this is merely speculative and should be clarified in future research. Above all, the clinical management of implants in SOT should always follow a rigorous and tight follow-up regimen to secure always states of health and prevent potential deleterious consequences.

Regarding MBL, it has been known from studies in immunosuppressed animal models that this condition apparently does not disturb bone density and implant osseointegration [39,40].

\subsection{Quality of the Evidence, Limitations, and Potential Biases in the Review Process}

Drawing parallels with available reviews, some comparable populations are immunocompromised patients (HIV, chemotherapy, and autoimmune diseases, for instance), given the consequences of the long-lasting post-transplant medications [35,41]. Under this assumption, dental implant survival was found to be very high in immunocompromised patients [35]. Additionally, HIV infection is recognized as a non-serious threat to implant survival on short-term evaluation [35,41].

No significant effect of immunocompromised conditions on implant survival was detectable. Implant-based therapy in immunocompromised patients should not aggravate the general morbidity and must not interfere in life-saving therapies. Careful risk stratification prior to implant therapy is fundamental. To further decipher the role of immunosuppression on dental implantology, more data from controlled and randomized studies are needed.

In respect to the type of transplant recipients included in this study, several types of transplants were included, two on liver [27], one on renal [28], and two with mixed transplant types [31,32]. Overall, these results account for the most prevalent types (renal and liver transplantation) (WHO, 2016), but also the infrequent cases.

Despite the comprehensive protocol conducted in this review to appraise all evidence on dental implant failure rate and MBL in SOT populations, some limitations should be discussed. The number of available articles was small, and none of the included studies presented intervention designs. Future studies should consider intervention designs and longer follow-ups to further confirm our results. Further, the rationale used to categorize implant failure was very dissimilar, although it was not reflected in the levels of heterogeneity. Thus, future studies should employ up-to-date case definitions [42], as well as more detailed clinical data. However, the shortage in available studies precluded additional tests in biological surrogates comparison, for instance cytokines, as they were previously reported as increased in SOT patients [16] and publication bias inspection.

Notwithstanding, several strengths are worth mentioning. The residual level of heterogeneity observed in the reported estimates and the strict protocol endorse the validity of quantitative analyses. In addition, studies were carried out both in hospital and private-practice settings, which allows for generalized conclusions.

\section{Conclusions}

Solid-organ transplant patients pose no serious threat to implant survival. Overall, this group of patients presented lower levels of dental implant failure rate and marginal bone loss compared to otherwise healthy patients. Further intervention trials with larger sample size and longer follow-ups are necessary to confirm these summary results. 
Supplementary Materials: The following are available online at http://www.mdpi.com/2673-3943/1/2/8/s1, Table S1: PRISMA 2009 Checklist, Table S2: List of potentially relevant studies not included in the systematic review, along with the reasons for exclusion.

Author Contributions: Conceptualization, J.B., V.M., P.M.; methodology, J.B., V.M., P.M.; software, P.M.; validation, J.B., V.M., P.M.; formal analysis, M.P., P.M.; investigation, J.B., V.M., P.M.; writing—original draft preparation, M.P., J.B., V.M., J.J.M., R.A., P.M., J.M.C.; writing—review and editing, M.P., J.B., V.M., J.J.M., R.A., P.M., J.M.C. All authors have read and agreed to the published version of the manuscript.

Funding: This work is financed by national funds through the FCT—Foundation for Science and Technology, I.P., under the project UIDB/04585/2020.

Conflicts of Interest: The authors declare no conflict of interest.

\section{References}

1. Jung, R.E.; Zembic, A.; Pjetursson, B.E.; Zwahlen, M.; Thoma, D.S. Systematic review of the survival rate and the incidence of biological, technical, and aesthetic complications of single crowns on implants reported in longitudinal studies with a mean follow-up of 5 years. Clin. Oral Implant. Res. 2012, 23, 2-21. [CrossRef] [PubMed]

2. Pjetursson, B.E.; Thoma, D.; Jung, R.; Zwahlen, M.; Zembic, A. A systematic review of the survival and complication rates of implant-supported fixed dental prostheses (FDPs) after a mean observation period of at least 5 years. Clin. Oral Implant. Res. 2012, 23, 22-38. [CrossRef] [PubMed]

3. Hjalmarsson, L.; Gheisarifar, M.; Jemt, T. A systematic review of survival of single implants as presented in longitudinal studies with a follow-up of at least 10 years. Eur. J. Oral Implantol. 2016, 9, S155-S162. [PubMed]

4. Bornstein, M.M.; Cionca, N.; Mombelli, A. Systemic conditions and treatments as risks for implant therapy. Int. J. Oral Maxillofac. Implant. 2009, 24, 12-27.

5. Roos-Jansaker, A.-M.; Lindahl, C.; Renvert, H.; Renvert, S. Nine- to fourteen-year follow-up of implant treatment. Part II: Presence of peri-implant lesions. J. Clin. Periodontol. 2006, 33, 290-295.

6. Diz, P.; Scully, C.; Sanz, M. Dental implants in the medically compromised patient. J. Dent. 2013, 41, $195-206$. [CrossRef]

7. Scully, C.; Hobkirk, J.; Dios, P.D. Dental endosseous implants in the medically compromised patient. J. Oral Rehabil. 2007, 34, 590-599. [CrossRef]

8. Heckmann, S.M.; Heckmann, J.G.; Linke, J.J.; Hohenberger, W.; Mombelli, A. Implant Therapy Following Liver Transplantation: Clinical and Microbiological Results After 10 Years. J. Periodontol. 2004, 75, 909-913. [CrossRef]

9. Mombelli, A.; Cionca, N. Systemic diseases affecting osseointegration therapy. Clin. Oral Implant. Res. 2006, 17, 97-103. [CrossRef]

10. Guggenheimer, J.; Eghtesad, B.; Stock, D.J. Dental management of the (solid) organ transplant patient. Oral Surg. Oral Med. Oral Pathol. Oral Radiol. Endodontology 2003, 95, 383-389. [CrossRef]

11. Hernández, G.; Jiménez, C.; Arriba, L.; Moreno, E.; Lucas, M. Resolution of oral ulcerations after decreasing the dosage of tacrolimus in a liver transplantation recipient. Oral Surg. Oral Med. Oral Pathol. Oral Radiol. Endodontol. 2001, 92, 526-531. [CrossRef] [PubMed]

12. GODT 2016. Available online: http://www.transplant-observatory.org/download/2016-activity-data-report/ (accessed on 2 June 2020).

13. Kritikos, A.; Manuel, O. Bloodstream infections after solid-organ transplantation. Virulence 2016, 7, 329-340. [CrossRef] [PubMed]

14. Fishman, J.A. Infection in Organ Transplantation. Am. J. Transpl. 2017, 17, 856-879. [CrossRef] [PubMed]

15. Kassebaum, N.J.; Bernabé, E.; Dahiya, M.; Bhandari, B.; Murray, C.J.L.; Marcenes, W. Global Burden of Severe Periodontitis in 1990-2010. J. Dent. Res. 2014, 93, 1045-1053. [CrossRef]

16. Machado, V.; Botelho, J.; Lopes, J.; Patrão, M.; Alves, R.; Chambrone, L.; Alcoforado, G.; Mendes, J.J. Periodontitis impact in interleukin-6 serum levels in solid organ transplanted patients: A systematic review and meta-analysis. Diagnostics 2020, 10, 184. [CrossRef]

17. De Molon, R.S.; Sakakura, C.E.; Faeda, R.S.; Sartori, R.; Palhares, D.; Margonar, R.; Marcantonio, E. Effect of the long-term administration of Cyclosporine A on bone healing around osseointegrated titanium implants: A histomorphometric study in the rabbit tibia. Microsc. Res. Tech. 2017, 80, 1000-1008. [CrossRef] 
18. Duarte, P.M.; Filho, G.R.N.; Sallum, E.A.; de Toledo, S.; Sallum, A.W.; Nociti, F.H. The Effect of an Immunosuppressive Therapy and Its Withdrawal on Bone Healing Around Titanium Implants. A Histometric Study in Rabbits. J. Periodontol. 2001, 72, 1391-1397. [CrossRef] [PubMed]

19. Sakakura, C.E.; Margonar, R.; Holzhausen, M.; Nociti, F.H.; Alba, R.C.; Marcantonio, E. Influence of Cyclosporin A Therapy on Bone Healing Around Titanium Implants: A Histometric and Biomechanic Study in Rabbits. J. Periodontol. 2003, 74, 976-981. [CrossRef]

20. Sakakura, C.E.; Margonar, R.; Sartori, R.; Morais, J.A.N.D.; Marcantonio, E. The Influence of Cyclosporin A on Mechanical Retention of Dental Implants Previously Integrated to the Bone: A Study in Rabbits. J. Periodontol. 2006, 77, 2059-2062. [CrossRef]

21. López-Pintor, R.M.; Hernández, G.; de Arriba, L.; de Andrés, A. Lip cancer in renal transplant patients. Oral Oncol. 2011, 47, 68-71. [CrossRef]

22. Renvert, S.; Persson, G.R.; Pirih, F.Q.; Camargo, P.M. Peri-implant health, peri-implant mucositis, and peri-implantitis: Case definitions and diagnostic considerations. J. Clin. Periodontol. 2018, 45, S278-S285. [CrossRef] [PubMed]

23. Patini, R.; Staderini, E.; Lajolo, C.; Lopetuso, L.; Mohammed, H.; Rimondini, L.; Rocchetti, V.; Franceschi, F.; Cordaro, M.; Gallenzi, P. Relationship between oral microbiota and periodontal disease: A systematic review. Eur. Rev. Med. Pharmacol. Sci. 2018, 22, 5775-5788. [PubMed]

24. Staderini, E.; Patini, R.; Guglielmi, F.; Camodeca, A.; Gallenzi, P. How to Manage Impacted Third Molars: Germectomy or Delayed Removal? A Systematic Literature Review. Med. (B. Aires) 2019, 55, 79.

25. Cajanding, R. Immunosuppression following organ transplantation. Part 2: Complications and their management. Br. J. Nurs. 2018, 27, 1059-1065.

26. Gu, L.; Yu, Y.C. Clinical outcome of dental implants placed in liver transplant recipients after 3 years: A case series. Transplant. Proc. 2011, 43, 2678-2682. [CrossRef] [PubMed]

27. Paredes, V.; López-Pintor, R.M.; Torres, J.; de Vicente, J.C.; Sanz, M.; Hernández, G. Implant treatment in pharmacologically immunosuppressed liver transplant patients: A prospective-controlled study. Clin. Oral Implant. Res. 2018, 29, 28-35. [CrossRef] [PubMed]

28. Hernández, G.; Paredes, V.; López-Pintor, R.M.; de Andrés, A.; de Vicente, J.C.; Sanz, M. Implant treatment in immunosuppressed renal transplant patients: A prospective case-controlled study. Clin. Oral Implant. Res. 2019, 30, 524-530. [CrossRef] [PubMed]

29. Montebugnoli, L.; Venturi, M.; Cervellati, F. Bone response to submerged implants in organ transplant patients: A prospective controlled study. Int. J. Oral Maxillofac. Implant. 2012, 27, 1494-1500.

30. Liberati, A.; Altman, D.G.; Tetzlaff, J.; Mulrow, C.; Gøtzsche, P.C.; Ioannidis, J.P.A.; Clarke, M.; Devereaux, P.J.; Kleijnen, J.; Moher, D. The PRISMA statement for reporting systematic reviews and meta-analyses of studies that evaluate health care interventions: Explanation and elaboration. PLoS Med. 2009, 6. [CrossRef]

31. Radzewski, R.; Osmola, K. The use of dental implants in organ transplant patients undergoing immunosuppressive therapy: An overview of publications. Implant Dent. 2016, 25, 541-546. [CrossRef]

32. Montebugnoli, L.; Venturi, M.; Cervellati, F.; Servidio, D.; Vocale, C.; Pagan, F.; Landini, M.P.; Magnani, G.; Sambri, V. Peri-Implant Response and Microflora in Organ Transplant Patients 1 Year after Prosthetic Loading: A Prospective Controlled Study. Clin. Implant Dent. Relat. Res. 2015, 17, 972-982. [CrossRef] [PubMed]

33. Howe, M.S.; Keys, W.; Richards, D. Long-term (10-year) dental implant survival: A systematic review and sensitivity meta-analysis. J. Dent. 2019, 84, 9-21. [CrossRef] [PubMed]

34. Moraschini, V.; Poubel, L.A.D.C.; Ferreira, V.F.; Barboza, E.D.S.P. Evaluation of survival and success rates of dental implants reported in longitudinal studies with a follow-up period of at least 10 years: A systematic review. Int. J. Oral Maxillofac. Surg. 2015, 44, 377-388. [CrossRef] [PubMed]

35. Duttenhoefer, F.; Fuessinger, M.A.; Beckmann, Y.; Schmelzeisen, R.; Groetz, K.A.; Boeker, M. Dental implants in immunocompromised patients: A systematic review and meta-analysis. Int. J. Implant Dent. 2019, 5, 1-12. [CrossRef]

36. Patini, R.; Staderini, E.; Camodeca, A.; Guglielmi, F.; Gallenzi, P. Case Reports in Pediatric Dentistry Journals: A Systematic Review about Their Effect on Impact Factor and Future Investigations. Dent. J. 2019, 7, 103. [CrossRef]

37. Anderson-Smits, C.; Baker, E.R.; Hirji, I. Coinfection rates and clinical outcome data for cytomegalovirus and Epstein-Barr virus in post-transplant patients: A systematic review of the literature. Transpl. Infect. Dis. 2020, 1-14. [CrossRef] 
38. Akram, Z.; Al-Aali, K.A.; Alrabiah, M.; Alonaizan, F.A.; Abduljabbar, T.; AlAhmari, F.; Javed, F.; Vohra, F. Current weight of evidence of viruses associated with peri-implantitis and peri-implant health: A systematic review and meta-analysis. Rev. Med. Virol. 2019, 29, e2042. [CrossRef]

39. Gonçalves, P.F.; Filho, G.D.R.N.; Sallum, E.A.; Sallum, A.W.; Junior, F.H.N. Immunosuppressant therapy and bone loss in ligature-induced periodontitis: A study in rats. Pesqui. Odontolog. Bras. 2003, 17, 46-50. [CrossRef]

40. Duarte, P.M.; Filho, G.R.N.; Sallum, E.A.; Sallum, A.W.; Júnior, F.H.N. Short-term immunosuppressive therapy does not affect the density of the pre-existing bone around titanium implants placed in rabbits. Pesqui. Odontolog. Bras. 2003, 17, 362-366. [CrossRef]

41. Sivakumar, I.; Arunachalam, S.; Choudhary, S.; Buzayan, M.M. Does HIV infection affect the survival of dental implants? A systematic review and meta-analysis. J. Prosthet. Dent. 2020, 1-8. [CrossRef]

42. Alsaadi, G.; Quirynen, M.; Komárek, A.; van Steenberghe, D. Impact of local and systemic factors on the incidence of late oral implant loss. Clin. Oral Implant. Res. 2008, 19, 670-676.

(C) 2020 by the authors. Licensee MDPI, Basel, Switzerland. This article is an open access article distributed under the terms and conditions of the Creative Commons Attribution (CC BY) license (http://creativecommons.org/licenses/by/4.0/). 